\title{
STAMBUL AND SOFIA UNIVERSITIES IN THE DESTINY OF THE SCIENTIST-BIOCHEMISTS AND THE DOCTORS OF THE WORLD
}

\author{
C Eleonora A. Reshetnikova, Elena K. Sklyarova, Olga N. Kamalova \\ Rostov state medical university. Rostov-on-Don, Russian Federation \\ science-almanac@mail.ru
}

The article for the first time compares the formation features of the scientific and pedagogical staff of the Istanbul and Sofia universities in the XX century. This topic has not received comprehensive coverage in the domestic historiography on the history of medicine and pharmacy, chemistry and biochemistry. Istanbul University has firmly entered the scientific world community, especially after the scientific discoveries of the medical faculty graduate of this university A. Sandzhar. Professor of Biochemistry and Radiology A. Sandzhar in the XXIst century is one of the leading biochemists and molecular biologists of the world, whose scientific research was published at the University of Oxford in the United Kingdom, in the encyclopedia of molecular biology in New York. The scientist shared the Nobel Prize with a Swede and an American with the phrase "for studying the mechanisms of DNA reconstruction", explaining the mechanisms by which the cells protect genetic information from damage. Conclusions of scientists will form the basis for the development of further ways to struggle cancer diseases. A. Sandzhar became the first graduate of the medicine faculty of Istanbul university, who received the Nobel Prize in chemistry. Professor, founder of analytical chemistry, the first president of the "Bulgaria Chemists Union" Z. Karaoglanov, who formulated one of the first equations of electrochemical kinetics, became the author of the first Bulgarian textbook on analytical chemistry, published in Sofia University, glorified the Sofia University. Professor K. S. Agadjanyants taught in the Russian Imperial University of Warsaw, Don University during the First World War, and after the Russian Revolution of 1917 and political emigration he taught at the Universities of Constantinople and Sofia. This became a factor that determined for many years the silence of scientific research about his contribution to the development of the Don and the Black Sea science universities. Professors of the Istanbul and Sofia universities perfectly mastered several foreign languages, which allowed them to work in the universities of the world. Istanbul and Sofia universities have become centers of emigration, as well as training and research activities of the world's leading specialists in the fields of medicine and pharmacy, chemistry and biochemistry, including Nobel Prize laureates.

Key words: Sofia University, Constantinople University, Don University, Warsaw University, biochemistry, history of medicine.

\section{[Э.А. Решетникова, Е.К. Склярова, О.Н. Камалова Стамбульский и Софийский университеты в судьбе ученых-биохимиков и врачей мира]}

Впервые сравниваются особенности формирования научно-педагогических кадров Стамбульского и Софийского университетов в XX в. Эта тема не получила всестороннего освещения в отечественной историографии по истории медицины и фармации, химии и биохимии. Стамбульский университет прочно вошел в научное мировое сообщество, особенно после научных открытий выпускника медицинского факультета этого университета А. Санжара. Профессор биохимии и радиологии А. Санджар в XXI в. является одним из ведущих биохимиков и молекулярных биологов мира, научные исследования которого опубликованы в университете Оксфорда в Великобритании, в энциклопедии молекулярной биологии в Нью-Йорке. Ученый разделил Нобелевскую премию со шведом и американцем с формулировкой «за исследование механизмов восстановления ДНК», объяснив механизмы, с помощью которых клетки защищают генетическую инфрормацию от повреждений. Выводы ученых станут основой разработки дальнейших способов борьбы с онкологическими заболеваниями. А. Санджар стал первым выпускником медицинского фракультета Стамбульского университета, получившим Нобелевскую премию по химии. Прославил Софийский университет профессор, основоположник аналитической химии, первый президент «Союза химиков Болгарии» 3. Караогланов, который сформулировал одно из первых уравнений электрохимической кинетики, получивших его имя, став автором первого болгарского учебника по аналитической химии, изданном в Софийском университете. Профессор К. С. Агаджанянц в годы Первой мировой войны преподавал в русском Императорском Варшавском университете, Донском университете, а после Русской революции 1917 г. и политической эмиграции препода- 
вал в Константинопольском и Софийском университетах. Это стало фактором, определившим на многие годы замалчивания научных исследований о его вкладе в развитие науки университетов Дона и Причерноморья. Профессора Стамбульского и Софийского университетов в совершенстве владели несколькими иностранными языками, что позволило им работать в университетах мира. Стамбульский и Софийский университеты стали центрами эмиграции, а также подготовки и научной деятельности ведущих специалистов мира в области медицины и фармации, химии и биохимии, в том числе лауреатов Нобелевской премии.

Ключевые слова: Софийский университет, Стамбульский университет, Константинопольский университет, Донской университет, Варшавский университет, биохимия, история медицины.

Eleonora A. Reshetnikova - candidate of biology, associate professor. Rostov state medical university. Rostov-on-Don, Russian Federation.

Elena K. Sklyarova - candidate of history, associate professor. Rostov state medical university. Rostov-onDon, Russian Federation.

Olga N. Kamalova - candidate of philosophy, associate professor. Rostov state medical university. Rostovon-Don, Russian Federation.

Решетникова Элеонора Анатольевна - кандидат биологических наук, доцент. Ростовский государственный медицинский университет. Ростов-на-Дону, Россия.

Склярова Елена Константиновна - кандидат исторических наук, доцент. Ростовский государственный медицинский университет. Ростов-на-Дону, Россия.

Камалова Ольга Николаевна - кандидат философских наук, доцент. Ростовский государственный медицинский университет. Ростов-на-Дону, Россия.

The relevance of the scientific and teaching activities research of biochemists and doctors of the Istanbul and Sofia universities possesses scientific and practical nature. In addition, this topic has not received comprehensive coverage in the domestic historiography on the history of medicine and pharmacy, chemistry and biochemistry. However, it should be noted that Istanbul and Sofia universities became centers of training and scientific activity of the world's leading specialists in the field of various sciences, including Nobel Prize laureates. A native of Turkey, biochemist scientist Aziz Sandzhdar received the Nobel Prize in chemistry in 2015, sharing it with swede T. Lindal and american P. Modric with the phrase "for studying the mechanisms of DNA repair". The scientists of the world who divided the prize independently explained the mechanisms by which cells "repair" their DNA and, thus, protect genetic information from damage. Before that, in the 1960s the scientific community was confident that DNA molecules are durable and practically unchanged throughout the organisms life. A few years before the discovery of A. Sandzhar, the largest scientific achievements were studies on the production of induced stem cells, the discovery of molecular principles for the organization of the transport system inside the cell, the discovery of cells that make up the positioning system in the brain.

A. Sandzhdar was a graduate of the Medical Faculty of Istanbul University. After receiving the diploma of a doctor in Istanbul, he worked for several years as a village doctor, and in 1973 became interested in biochemistry. He was amazed that the bacteria, after receiving a deadly dose of ultraviolet light, restore their strength quickly after exposure by the blue light in the visible range. Despite the fact that his parents had no education, all children in their many-child family received higher education. He was born in 1946 in the southeast of Turkey on the border with Syria, and in 1971 he emigrated to the United States, where he continued his education after completing a postgraduate course in molecular biology at the University of Texas in Dallas. In the USA, in the Texas laboratory, he successfully cloned the gene of the enzyme responsible for the elimination of damage from ultraviolet (photolyases). In the 1970s. this discovery did not cause any interest in American universities, and he had to work as a simple laboratory assistant in the Yale University Medical 
Laboratory. In 1969-1971, and in 1972-1973 years he was engaged in medical practice in Turkey. In 1982 - 1988 became a professor of biochemistry and radiology at the University of North Carolina.

A. Sandzhar became the first graduate of the faculty of medicine of Istanbul university, who received the Nobel Prize in chemistry, and also the first representative of Turkey in the US Academy of Sciences, the second representative of Turkey, who received the prestigious Nobel Prize. Before him, only in 2006, the writer O. Pamuk was awarded the Nobel Prize, but in literature. For comparison, it should be noted that the only Russian Nobel laureate $\mathrm{N}$. Semenov is one of the founders of chemical physics in chemistry. He received the Nobel Prize in 1956, together with the Englishman S. Hinshelwood, for studying the mechanisms of chemical transformations. The main contribution of N. Semenov was that he developed the theory of chain reactions. Institute of Chemical Physics of the Russian Academy of Sciences was called by his name. "Studies of biochemists of the USSR have won an honorary place in the world biochemical science. A great contribution to the development of biochemistry was made by scientists from the Institute of Prince A. Oldenburg, the Central Chemical Laboratory under the Supreme Council of the National Economy of the RSFSR, the Biochemistry Institute of the USSR Academy of Sciences" [8, p. 47].

In terms of the number of Nobel Prizes, the leading places in the world are occupied by the USA, Great Britain, Germany, France, Sweden, Switzerland and Australia. There is no Turkey in this list yet. However, A. Sandzhar, a graduate of the medicine faculty at Istanbul university, is one of the world's leading biochemists and molecular biologists, whose scientific research was published at the University of Oxford in the United Kingdom [16], the encyclopedia of molecular biology in New York [17]. The Nobel Prize on chemistry was predicted by his compatriots at the popular Turkish forum Eksi Sozluk. Since 2006 A. Sandzhar became a member of Turkish Academy of Sciences. A graduate of the medicine faculty of Istanbul university is confident that his research will help to fight cancer. His name should rightfully be included in the textbooks on the history of medicine and pharmacy, where it was noted that a couple of years before him, the Nobel Prize was awarded to scientists from "Yale, California and Stanford University" [10, p. 271].

Istanbul (Constantinople) University is the oldest university in Turkey, founded after the capture of Constantinople in the 15th century. Until the 20th c. the university was the highest Muslim school, and after the proclamation of the Turkish Republic was reorganized in 1923-1933, becoming a secular educational institution. As a result of the Ottoman Empire defeat in the First World War and its division in 1923, the monarchy was abolished, and the former territory of the Omani Empire was transformed into the Turkish national state. Before that, Constantinople for centuries was a part of the Byzantine Empire.

The scientific library of the Istanbul State University was founded in 1925, becoming one of the largest libraries in Turkey, the fund of which has several thousand manuscripts. The official name of Constantinople and Constantinople university was preserved until 1930. In the 21st century, Istanbul University is the only university in Turkey, included in the list of 2011 as the best universities in the world. Istanbul State University is also among the best universities in the world on the list in the Asia-Pacific region. In the XXI c. Istanbul has become the scientific center of Turkey, where there are several state universities and scientific societies. The largest educational institution is the Istanbul University, on the basis of which the Turkish Medical Society, the Turkish Biological Society, and the Turkish Chemical Society are operated.

Remzier Hissar (1902-1992) was the first Turkish woman chemist who glorified Istanbul university. She initially held positions in various universities in Turkey, published many scientific articles on metaphosphates and Turkish herbs. She is considered to be the first among the women scientists in modern history of Turkey. With the appointment of her father to a new place of work, the family moved to Istanbul. R. Hisar received a natural-science 
education in "Daru'ul-Fyunun" (the predecessor of modern Istanbul University), where her main scientific interest was chemistry. She graduated with honors in 1919 and moved to Baku to work in a pedagogical school, where she met R. Sureya (Gursey), a doctor of medicine from Turkey. They got married. Soon, shortly before the entry of the Red Army into Azerbaijan, they returned to Turkey to Istanbul. And then she followed her husband to Paris to complete higher education, having received a chemical education at the Sorbonne University, being a pupil of Marie Curie [15, p. 14]. She received a scholarship from the Government of Turkey, becoming the first Turkish woman, who received a biochemistry certificate at the Sorbonne. R. Hissar conducted metaphosphate research with P. Pascal, received a doctorate. In 1933, she returned to Turkey, where she was appointed assistant professor of the Department of General Chemistry and Physical Chemistry at the University of Istanbul. In 1959 she became a professor. Her scientific research was devoted to metaphosphates and Turkish herbs. In 1991, she received a prize from the Council of Turkey for Scientific and Technical Research (TÜBITAK).

A special place in the history of science is occupied by the Sofia State University in Bulgaria, founded in 1888. It is the oldest university in Bulgaria, which bears the name of Archbishop Clement of Ohrid, one of the founders of the Slavonic alphabet. The modern building was built in 1924-1934. The medical faculty of this university was established in 1917, and the Veterinary Department in 1923. In 1929 in Sofia University the doctoral dissertations for the first time began to be defended. In 1920-1940, professors forced to emigrate from the university who did not agree to cooperate with the communist authorities. The department of chemistry and pharmacy was established in 2012.

Sofia University Professor Professor, founder of analytical chemistry Zakhari Velichkov Karaoglanov (1878-1943) glorified Sofia University. Bulgarian chemist, specialist in inorganic chemistry was a professor, and also rector of Sofia University in 1922-1923, and in 1932-1933. He is also a graduate of Sofia University, where he studied chemistry, graduating from university in 1902. He took practical study in Leipzig in 1903-1904., and then in Berlin in 1911. Returning to Bulgaria, Z. V. Karaoglanov became an assistant since 1907, from 1910-an associate professor, and since 1915 - a professor of Sophia University. Since 1920, Z.V. Karaoglanov has already headed the department of analytical chemistry of the physico-mathematical faculty of the Sofia State University. Successfully engaged in scientific activity, he also became the dean of this faculty in 1921-1922, and then in 1928-1929. In 1924-1929 Z.V. Karaoglanov headed the "Union of Bulgarian Chemists", became his first president.

The scientific activity of professor Z.V. Karaoglanov was connected with the study of mechanisms and sensitivity to analytical reactions. He is the author of the first Bulgarian textbook on inorganic chemistry for universities. His scientific works were also devoted to analytical chemistry, chemical research of the composition of the Black Sea water and some lakes on the Black Sea coast. His textbooks on analytical chemistry were published in the Sofia University $[5,6]$. It should be noted that the professors of the Istanbul and Sofia universities perfectly mastered several foreign languages, which enabled them to work in the universities of the world. For instance, the doctor of medicine, professor K.S. Agadzhanyants (1876-1955) "after the October Revolution of 1917 and the Civil War in 1920, for political reasons emigrated to Turkey and then to Bulgaria" [14, p. 97].

Professor K.S. Agadzhanyants taught at the Don University, and after emigration in Constantinople and Sofia universities. This became a factor that determined for many years the silence of scientific research on its contribution to the development of medicine in the Don and the Black Sea" [13, 41-47]. Psychiatrist, neurologist, neuroanatom participated in the IX Pirogov Congress of Physicians with a report on the role of psychotherapy in dermatology [1, p. 404]. K.S. Aghajanyants was "a graduate of the St. Petersburg Military Medical 
Academy, a student of V.M. Bekhterev" [7, c. 24]. In 1906, he participated in the 15th International Medical Congress in Lisbon, and in 1910 he trained in Berlin under the supervision of the German neurologist L. Jacobson [2, p. 67]. In 1913-1915 K.S. Aghajanyants already taught at the Department of Psychiatry of the Russian Imperial University of Warsaw, which during the First World War was evacuated to Rostov-on-Don. In the North Caucasus, Professor K.S. Agadzhanyants became a consultant on the nervous diseases of the Southern (Caucasian) Front, worked in the Red Cross, dealt with the evacuation of mentally ill soldiers of the Caucasus Front [2, p. 67]. For work in the Red Cross, he was awarded the Order of St. Anna of the III degree, a sign of the Red Cross. The professor became the first "head of the nervous and mental illnesses department of the Don University medical faculty in 19171920. [4, p. 25]. For comparison, it should be noted that "By the beginning of the Great Patriotic War, the system of higher education in the North Caucasus was only developing. The oldest universities were no more than a quarter of a century" [11, p. 109]. "The Fund of literature of the Warsaw university was during the First World War in 1915 the foundation of the medical faculty library funds of the Don University" [12, p. 35].

After the Russian Revolution of 1917 and the Civil War in 1920, "without recognizing the policies of the Bolsheviks, K.S. Agadzhanyants was forced to emigrate to Turkey, to the city of Constantinople, where in 1922 he already taught at the Constantinople University (Istanbul). In 1922-1924 the professor already lived and worked in Bulgaria, where he became a professor at the law faculty of Sofia University [9]. In 1924 he emigrated from Bulgaria to France, where in 1928 he defended his doctoral dissertation at the Sorbonne University. In 1950 he was elected chairman of the Union of Russian Armenians in France.

Thus, it should be noted that the Istanbul and Sofia universities in the XX-XXI c. became the centers of scientific emigration, as well as training and research activities of the world's leading specialists in the fields of medicine and pharmacy, chemistry and biochemistry, including Nobel Prize winners. Istanbul University has firmly established itself in the scientific world community, especially after the scientific discoveries of A. Sanjar, who shared the Nobel Prize with a Swede and an American with the phrase "for studying the mechanisms of DNA reconstruction", explaining the mechanisms by which cells protect genetic information from damage. Studies of the graduate of the medical faculty of the University of Istanbul will form the basis for the development of further ways to combat oncological diseases. V. Karaoglanov laid the foundations of the volt-ampere metry, formulated one of the first equations of electrochemical kinetics that received his name, became the author of the first Bulgarian textbook on inorganic chemistry for universities published in the University of Sofia. Professor K.S. Agadzhanyants after the Russian Revolution of 1917, emigrated from Russia, taught at Constantinople and Sofia universities, which became a factor that determined the silence of his contribution to the development of the universities of the Don and the Black Sea science. Professors of the Istanbul and Sofia universities perfectly mastered several foreign languages, which enabled them to engage in scientific activities in various universities around the world. The First World War forced the emigration of professors from Warsaw, Don, and Istanbul universities. In the XXc. Sofia and Istanbul universities have become centers of scientific emigration and scientific research of the world's leading scientists in the fields of medicine and pharmacy, chemistry and biochemistry, including Nobel Prize laureates. 


\section{Лumepamypa}

1. Агаджаняни К.С. Роль психотерапии в дерматологии // Русский врач. 1917.

2. Бутова Е.Н., Склярова Е.К., Сидоренко Ю.А. Врачи Дона и Пироговское общество (к 100-летию Русской революции 1917 г.) // Гуманитарные и социальноэкономические науки. 2017. № 5 (96).

3. Вузы Северного Кавказа в годы Великой Отечественной войны / Е.К. Склярова, М.А. Гутиева, А.В. Карташев, О.Н. Камалова. Ростов н/Д, 2016.

4. История кафедры психиатрии Ростовского государственного медицинского университета. От Императорского Варшавского университета до наших дней / под. ред. А.О. Бухановского, В.И. Солдаткина. Ростов н/Д, 2014.

5. Караогланов З.В. Ръководство по аналитическа химия. Часть 1. Ккчественъ анализъ. София, 1923.

6. Караогланов 3.В. Ръководство по аналитическа химия. Часть 2. Количествен анализ. Софиия, 1924.

7. Наследники духовных традиций медицины / Е.В. Харламов, Е.К. Склярова, А.А. Сависько, Ю.А. Сидоренко. Ростов н/Д, 2016.

8. Решетникова Э.А., Склярова Е.К., Ветрова Е.В. Становление биохимических исследований в России // Гуманитарные и социально-экономические науки. 2017. № 3. С. 47.

9. Русская газета. 2012. 16 июля.

10. Склярова Е.К., Камалова О.Н. История фрармации. Ростов н/Д: Феникс, 2017.

11. Становление высшего медицинского образования на Северном Кавказе 1915 1945 / А.В. Карташев, Е.К. Склярова, Р.С. Спевак, О.Н. Камалова. Ставрополь, 2017.

12. Харламов Е.В. Деонтология жизни. Ростов н/Д, 2015.

13. Drobotya N., Chaplygina E., Kamalova O., Sklyarova E. Contribution of researchers of Rostov State Medical University to health development of Black Sea region // Научный альманах стран Причерноморья. 2017. № 1 (9).

14. English Medium: History / E.K. Sklyarova, M.A., Gutieva, G.Sh. Gafiyatullina, O.N. Kamalova. Ростов н/Д: ЮФУ, 2018.

15. "MARIE CURIE'NIN ÖĞRENCISI KIMYA BILIMMCI REMZIYE HISAR" // Mimoza. 2015. № 3.

16. Sancar A. Recognition of DNA damage and repair / In: Proteins that Manipulate DNA structure / Ed. by D.M. Lilley. Oxford: Oxford University Press, 1995.

17. Sancar A. Thompson C. Base excision repair / In: Encyclopedia of Molecular Biology / Ed. by T. E. Creighton. New Yor: John Wiley \& Sons, Inc., 2002.

\section{References}

1. Aghajanyants K.S. The Role of Psychotherapy in Dermatology // Russian Physician. 1917.

2. Butova E.N., Sklyarova E.K., Sidorenko Yu.A. The Doctors of the Don and the Pirogov Society (on the occasion of the 100th anniversary of the Russian Revolution of 1917) // Humanitarian and socioeconomic sciences. 2017. No 5 (96).

3. Higher educational institutions of the North Caucasus during the Great Patriotic War I E.K. Sklyarova, M.A. Gutiyeva, A.V. Kartashev, O.N. Kamalova. Rostov-on-Don, 2016. 
4. History of the Department of Psychiatry of the Rostov State Medical University. From the Imperial University of Warsaw to the present days / under. Ed. A.O. Bukhanovsky, V.I. Soldatkin. Rostov on Don, 2014.

5. Karaoglanov Z.V. Analytical chemistry. Part 1. Qualitative analysis. Sophia, 1923.

6. Karaoglanov Z.V. A guide to analytical chemistry. Part 2. Quantitative analysis. Sofia, 1924.

7. Heirs of the medicine spiritual traditions / E.V. Kharlamov, E.K. Sklyarova, A.A. Savisko, Yu.A. Sidorenko. Rostov on Don, 2016.

8. Reshetnikova E.A., Sklyarova E.K., Vetrova E.V. The formation of biochemical research in Russia // Humanitarian and socio-economic sciences. 2017. No 3.

9. The Russian newspaper. 2012. 16 of July.

10. Sklyarova EK, Kamalova O.N. History of Pharmacy. Rostov-on-Don, 2017.

11. Formation of higher medical education in the North Caucasus 1915-1945 / A.V. Kartashev, E.K. Sklyarova, R.S. Spevak, O.N. Kamalova. Stavropol, 2017.

12. Kharlamov E.V. Deontology of life. Rostov on Don, 2015.

13. Drobotya N., Chaplygina E., Kamalova O., Sklyarova E. Contribution of the Rostov State Medical University researchers to health development of Black Sea region // Science almanac of Black Sea region countries. 2017. No 1 (9).

14. English Medium: History / E.K. Sklyarova, M.A., Gutieva, G.Sh. Gafiyatullina, O.N. Kamalova. Rostov on Don: SFU, 2018.

15. "MARIE CURIE'NIN ÖĞRENCISI KIMYA BILIMMCI REMZIYE HISAR" // Mimoza. 2015. No 3.

16. Sancar A. Recognition of DNA damage and repair / In: Proteins that Manipulate DNA structure / Ed. by D.M. Lilley. Oxford: Oxford University Press, 1995.

17. Sancar A. Thompson C. Base excision repair / In: Encyclopedia of Molecular Biology / Ed. by T. E. Creighton. New Yor: John Wiley \& Sons, Inc., 2002. 